pdf/3000168/Коронавірусна\%20хвороба\%202019\%20\%28COVID$19 \% 29 . \mathrm{pdf}$

2. Соображения по вопросам массового лечения, активного выявления случаев и обследований населения в связи с забытыми тропическими болезнями в контексте пандемии COVID-19 . //Всемирная организация здравоохранения. - 2020 - Режим доступу до ресурсу: https://apps.who.int/iris/bitstream/handle/10665/333499/WHO-2019nCoV-neglected_tropical_diseases-2020.1-rus.pdf

3. Наказ МОЗ України від 17.09.2020 № 2122»Про внесення змін до Стандартів медичної допомоги «Коронавірусна хвороба (COVID-19)» від 17 вересня 2020 року.

DOI https://doi.org/10.30525/978-9934-588-81-5-1.25

\title{
ВПЛИВ ГІПЕРРЕАКТИВНОСТІ БРОНХІВ НА ЕФЕКТИВНІСТЬ ІНГАЛЯЦІЙНОЇ ТЕРАПІЇ У ДІТЕЙ 3 МУКОВІСЦИДОЗОМ
}

\author{
Ільченко С. I. \\ доктор медичних наук, \\ професор кафедри пропедевтики дитячих хвороб \\ Дніпропетровська медична академія \\ Міністерства охорони здоров'я Украӥни \\ Фіалковська А. О. \\ кандидат медичних наук, \\ дочент кафедри пропедевтики дитячих хвороб \\ Дніпропетровська медична академія \\ Міністерства охорони здоров'я Украӥни \\ Скрябіна К. В. \\ асистент кафедри пропедевтики дитячих хвороб \\ Дніпропетровська медична академія \\ Міністерства охорони здоров'я Украӥни \\ Іванусь С. Г. \\ кандидат медичних наук, \\ завідувач педіатричним відділенням \\ Комунальне некомериійне підприємство \\ «Міська дитяча клінічна лікарня № 6» Дніпровської міської ради
}




\section{Донець М. М. \\ лікар-пульмонолог \\ Комунальне некомериійне підприємство \\ «Міська дитяча клінічна лікарня № 6» Дніпровської міської ради \\ м. Дніпро, Украӥна}

Гіпертонічні розчини хлориду натрію (ГРХН) згідно з діючим уніфікованим клінічним протоколом входить до переліку обов'язкових муколітичніх препаратів, які отримують хворі на муковісцидоз (МB) [1]. Основний механізм його дії у хворих на MB - осмотична активність розчину, яка виводить рідину на апікальну поверхню епітелію дихальних шляхів і таким чином компенсує підвищену абсорбцію натрію, хлоридів і води, яка виникає у відсутності нормальної функції гена MB CFTR [2]. Однак, приблизно у 30 \% пацієнтів з MB виникає гіперреактивність бронхів на ГРХН [3]. Гіперреактивність бронхів у хворих на МВ може різко ускладнювати перебіг бронхолегеневого процесу, бути причиною поганого дотримання вимог лікування та припинення інгаляційної терапії.

Мета - дослідження впливу гіперреактивності бронхів на ефективність інгаляційної терапії сольовими розчинами у дітей з МВ.

Методи. Обстежено 34 дитини з МВ віком від 6 до 18 років (середній вік - 13,0 $\pm 4,4$ років), які знаходились на лікуванні у міському дитячому пульмонологічному центрі м. Дніпро. Дослідження включало три послідовні інгаляції тривалістю 2 хвилини кожна. Стерильний $0,9 \%$ розчин $\mathrm{NaCl}$ використовували для першої інгаляції, 3 \% розчин $\mathrm{NaCl}$ для другої і 7 \% розчин $\mathrm{NaCl}$ для третьої інгаляції. Спірометрія проводилася до і після кожної інгаляції, а також були проаналізовані клінічні зміни. Для статистичної обробки отриманих результатів використовувалася ліцензійна програма «Statistica 6.1» (серійний номер - AGAR909E415822FA).

Результати дослідження

На момент обстеження до проведення інгаляцій переважна більшість хворих $(75,0$ \%) скаржилася на вологий малопродуктивний кашель. Після інгаляцій ГРХН кашель став продуктивним у 50 \% хворих $(\mathrm{p}<0,05)$, при цьому достовірних клінічних відмінностей при використанні $3 \%$ розчину $\mathrm{NaCl}$ та $7 \%$ розчину $\mathrm{NaCl}$ не виявлено (p>0,05).

Вивчаючи переносимість інгаляцій ГРХН у пацієнтів були зареєстровані такі побічні явища, як першіння в горлі, утруднення дихання та спастичний кашель. При аналізі побічних явищ інгаляційної терапії ГРХН були виявлені статистично значущі відмінності (рис.). Так, скарги на першіння в горлі та утруднене дихання виникли лише після 
інгаляцій 7 \% розчину $\mathrm{NaCl}$. Спастичний кашель спостерігався у 5,9 \% хворих після інгаляцій $0,9 \%$ розчину $\mathrm{NaCl}$, у $11,8 \%$ хворих $(\mathrm{p}<0,05)$ після інгаляцій $3 \%$ розчину $\mathrm{NaCl}$ та у $23,5 \%$ хворих після інгаляцій 7 $\%$ розчину $\mathrm{NaCl}(\mathrm{p}<0,05)$. Аускультативні симптоми бронхоспазму достовірно частіше реєструвалися після інгаляцій $7 \%$ розчину $\mathrm{NaCl}$, ніж після $3 \%$ розчину $\mathrm{NaCl}(35,3 \%$ проти $5,9 \%$; $<0,001)$.

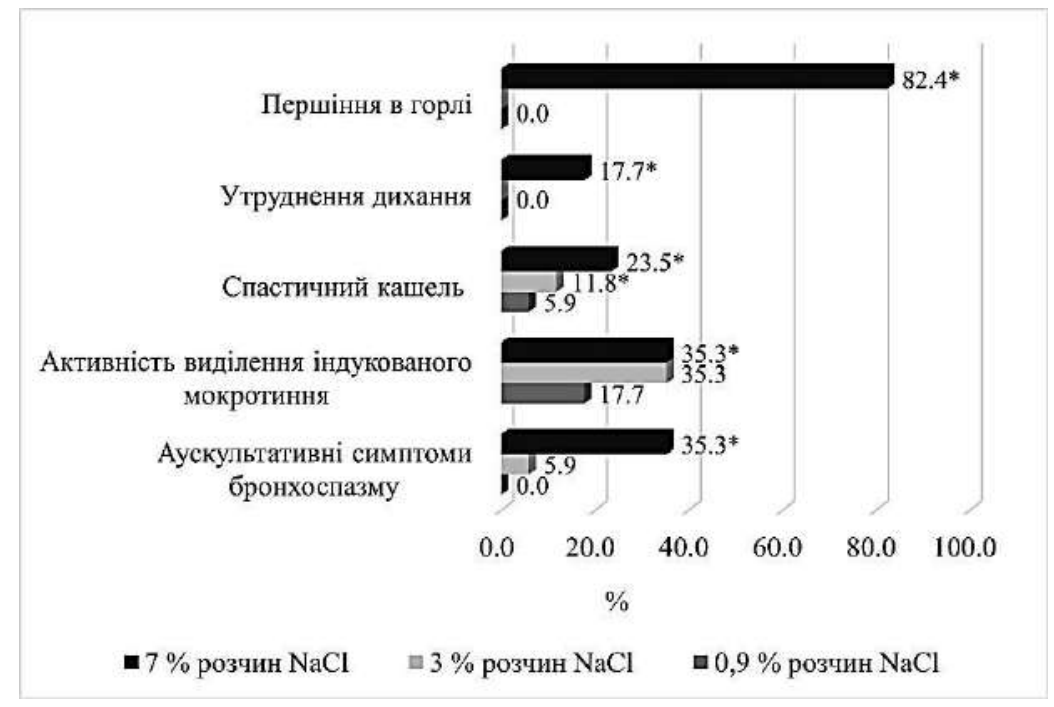

\section{Рис. Частота побічних явищ при використанні розчинів хлориду натрію різних концентрацій, \%}

Результати спірометричного дослідження показали, що після інгаляцій $0,9 \%$ розчином $\mathrm{NaCl}$ та $3 \%$ розчином $\mathrm{NaCl}$ достовірних відмінностей середніх показників функції зовнішнього дихання в порівнянні 3 вихідними середніми даними не виявлено ( $>0,05)$ (таб.). Інгаляції $7 \%$ розчином $\mathrm{NaCl}$ супроводжувались тенденцією до зниження середніх показників бронхіальної прохідності порівняно з вихідними даними (з $86,1 \pm 4,7 \%$ до $82,1 \pm 4,9 \%, \mathrm{p}<0,1)$.

Клінічно значиме зниження (більше 20 \%) ОФВ1 спостерігалося у $5,8 \%$ хворих після інгаляцій $3 \%$ розчином $\mathrm{NaCl}$ та у $11,8 \%$ хворих після інгаляцій $7 \%$ розчином $\mathrm{NaCl}$. Встановлено, що зниження ОФВ1 нижче $20 \%$ корелювало 3 клінічними симптомами бронхоспазму $(\mathrm{r}=+0,39, \mathrm{p}<0,05)$. Розвиток бронхоспазму у хворих на МВ різко 
ускладнює перебіг бронхолегеневого процесу - призводить до інтенсифікації інфекційного процесу і формування порочного кола: обструкція-інфекція-запалення з пошкодженням тканин легень. Клінічним проявом порочного кола є прогресуюче зниження функціональних показників дихання.

Таблиця

Показники функції зовнішнього дихання до та після інгаляцій розчинів натрію хлориду у хворих на МВ

\begin{tabular}{|c|c|c|c|c|}
\hline \multirow[b]{2}{*}{ Показники } & \multirow[b]{2}{*}{$\begin{array}{c}\text { До } \\
\text { інгаляцій }\end{array}$} & \multicolumn{3}{|c|}{ Після інгаляцій } \\
\hline & & $\begin{array}{c}0,9 \% \\
\text { розчин } \mathrm{NaCl}\end{array}$ & $\begin{array}{c}3 \% \text { розчин } \\
\mathrm{NaCl}\end{array}$ & $\begin{array}{c}7 \% \text { розчин } \\
\mathrm{NaCl}\end{array}$ \\
\hline $\mathrm{O \Phi B}_{1}, \%$ & $86,1 \pm 4,7$ & $84,5 \pm 4,8$ & $83,2 \pm 5,1$ & $82,1 \pm 4,9^{*}$ \\
\hline ФЖЕЛ, \% & $93,8 \pm 4,1$ & $92,6 \pm 4,5$ & $92,0 \pm 4,7$ & $91,4 \pm 4,8$ \\
\hline $\mathrm{OФB}_{1} / Ф Ж Е Л, \%$ & $84,6 \pm 6,2$ & $84,3 \pm 6,2$ & $83,3 \pm 6,4$ & $83,0 \pm 6,4$ \\
\hline ПСВ, $\%$ & $80,2 \pm 6,8$ & $77,9 \pm 7,1$ & $73,7 \pm 7,5$ & $75,5 \pm 7,4$ \\
\hline
\end{tabular}

Висновок. Таким чином ГРХН є сучасними і ефективними муколітичними лікарськими засобами. Призначення ГРХН дітям з МВ потребує проведення пробних інгаляцій під контролем спірометричного дослідження на початку лікування для визначення індивідуальної чутливості пацієнта та прогнозування позитивного терапевтичного ефекту.

\section{Література:}

1. Уніфікований клінічний протокол первинної, вторинної та третинної медичної допомоги «Муковісцидоз»: Наказ МОЗ України № 723 від 15.07.2016 p.

2. Шерман В. Д., Одинаева Н. Д., Черняк А. В. Исследование эффективности и переносимости медицинского изделия Гианеб и $7 \%$ гипертонического раствора $\mathrm{NACl}$ у детей с муковисцидозом. Сибирское медицинское обозрение. 2019. № (2). С. 102-106. DOI: 10.20333/2500136-2019-2-102-106.

3. Bronchial Hyperreactivity Related to Inhalation Therapy in Cystic Fibrosis Patients / H. Eyns et al. Journal of Pulmonary \& Respiratory Medicine. 2014. Vol. 4, Issue 6. P. 1-10. DOI:10.4172/2161105X.1000211. 